\title{
Reasoned fertilization of potato in response to Nitrogen supply in Andisols
}

\author{
Dante Pinochet $^{1 *}$, John Clunes $^{1,2^{*}}$, Claudio Gauna ${ }^{1}$, Andrés Contreras ${ }^{3 \dagger}$ \\ ${ }^{1}$ Faculty of Agricultural Sciences, Institute of Agricultural Engineering and Soils, University Austral of Chile. \\ Independencia 641, Valdivia, Chile. ${ }^{2}$ Graduate School, Faculty of Agricultural Sciences, University Austral of \\ Chile. Independencia 641, Valdivia, Chile. ${ }^{3}$ Faculty of Agricultural Sciences, Institute of Plant Production and \\ Protection, University Austral of Chile. Independencia 641, Valdivia, Chile. *Corresponding author: dpino- \\ che@uach.cl,johnclunes@gmail.com
}

\begin{abstract}
Using the reasoned nitrogen $(\mathrm{N})$ fertilization method in potato crops (Solanum tuberosum L.) requires the validation of its parameters under the probable conditions of crop response. A field experiment in an Andisol was established to assess the parameters of this method and the nitrogen utilization efficiency of the crop. To describe the crop $\mathrm{N}$ response, five statistical models were used. Dry matter production and nutrient concentration were measured in tubers, leaves, fruits and roots. At both the beginning and the end of the experiment soil samples were collected to evaluate the mineral $\mathrm{N}$. The quadratic-potential model was the most appropriate to describe the positive response of the potato crop to available nitrogen, from an initial level of nitrogen (the control, zero application ) to a maximum application of $200 \mathrm{~kg} \mathrm{~N} \mathrm{ha}^{-1}$. The relationship between the $\mathrm{N}$ doses and the potato yield reached a physical optimal of productivity at a rate of $228 \mathrm{~kg} \mathrm{~N} \mathrm{ha}^{-1}$. Higher rates $\left(300 \mathrm{~kg} \mathrm{~N} \mathrm{ha}^{-1}\right)$ resulted in a decrease in yield, generating phytotoxicity for cultivation. This variation allowed us to evaluate the reasoned application method under different nitrogen availabilities (deficiency, optimal and above-optimal) in addition to the variation of the parameters generated.
\end{abstract}

Keywords: Nitrogen fertilization, potato, use efficiency, optimum rate.

\section{Introduction}

Reasoned fertilization method aim to evaluate the fertilization needs of a crop based on the estimation of parameters that determine the three subcomponents of a predictive fertilization model (Rodríguez et al, 2001; Pinochet, 2005), including: crops' re- quirements (demand), the soil is capacity to supply a certain nutrient to a crop (supply) and the crop's capacity to absorb the nutrients applied through fertilization in a particular agro-ecosystem (fertilization efficiency). The parameters and coefficients 
required to define these subcomponents are the result of experimentation in an agro-ecosystem under optimum nutritional conditions (potential fertility with rational basis that considerate the integration of the soil properties) that are generally deficient only in relation to the supply of the evaluated nutrient. (Giletto et al., 2003; Moral and Rebolledo, 2017). These should be characteristic of the crop and/or agro-ecosystem and through a diagnostic method a nutrient dose is then established for successful cultivation in the agricultural ecosystem. These parameters must then be validated through field-testing (Rodríguez et al., 2001). Thus, the key to this methodology is the determination of the characteristic parameters of crops (total dry matter, harvest moisture, harvest index and internal $\mathrm{N}$ requirement), agro-ecosystems (precipitation and temperature) and fertilization technologies ( $\mathrm{N}$ levels) that could then form the basis that would allow us to apply this methodology to other agricultural systems.

Nitrogen $(\mathrm{N})$ is a primary nutrient, which, due to its limited availability to crops, presents itself as a limiting factor for the growth and development of plants in diverse agricultural ecosystems (Kraiser et al, 2011). N is absorbed from the soil solution and is used for various metabolic purposes, including the production of nucleic acids, protein formation and cofactors. It forms part of chlorophyll and is one of the primary components required for photosynthesis, as well as its role in signaling molecules and storage (Tisdale et al, 1993; McAllister et al., 2012). When the supply is deficient, fertilization is required to increase the $\mathrm{N}$ available at the level required by the crop (Rodríguez et al., 2001). A large part of the $\mathrm{N}$ added as fertilizer is lost to the environment through pathways to the air and the water subsurface and surfaces. It is generally accepted that crops recover, on average, between $40 \%$ and $60 \%$ of the fertilizer applied (Tyler et al., 1983); the rest of the applied fertilizer has proven to be lost in runoff, leaching of nitrates and nitrogen sources, denitrification into
$\mathrm{N}_{2}$ gaseous or $\mathrm{N}$ oxides, immobilization by bacterial competition and volatilization of ammonia $\left(\mathrm{NH}_{3}\right)$ in ammonia fertilizers (Garnett et al., 2009). Therefore, to develop effective nitrogen fertilization strategies it is essential to know the soil properties and fertility in addition to the $\mathrm{N}$ requirements, $\mathrm{N}$ uptake and $\mathrm{N}$ use efficiency of any given crop (Montemurro et $a l ., 2006)$. To properly estimate the efficiency of use, recovery of applied fertilizer should be considered. Nitrogen losses of $20 \%$ to immobilization and $15 \%$ to denitrification are accepted; which suggests that the efficiency of nitrogen fertilization is usually less than 65\% (Rodríguez et al., 2001).

Improving nitrogen use efficiency is especially important for potato crops because of their relatively low ability to take up available soil mineral nitrogen (Goffart et al., 2008). Furthermore, it is important to investigate the potato nitrogen uptake efficiency and risks of $\mathrm{N}$ fertilizer application before and at planting, considering the efficacy of these timing strategies in minimizing $\mathrm{N}$ losses (Rens et al., 2015). Therefore, we propose that it is necessary to validate the parameters for the reasoned fertilization of potato crops ( $\mathrm{So}$ lanum tuberosum L.) under the dryland conditions of the Valdivia agro-ecosystem.

\section{Materials and Methods}

The field trial was conducted at the Austral Experimental Station ( $39^{\circ} 47^{\prime} \mathrm{S}$ and $\left.73^{\circ} 14^{\prime} \mathrm{O}\right)$, which belongs to the Universidad Austral de Chile, Faculty of Agricultural Sciences located four kilometers north of the city of Valdivia. The Valdivia soil series is classified as a Duric Hapludand (Luzio and Casanova, 2006), known locally as Trumao, which is derived from volcanic ash on marine deposits (IREN$\mathrm{UACH}, 1978$ ). During the growing season, the average temperature varied between 9.8 and $17.2^{\circ} \mathrm{C}$ and monthly rainfall varied between 24.2 and $124.1 \mathrm{~mm}$. 
Therefore, the reasoned fertilization method was evaluated under the temperate rainy conditions of the
Valdivia agroecosystem. Analyses of the site's chemical parameters are shown in Table 1.

Table 1. Complete chemical analyses of soil.

\begin{tabular}{lcc}
\hline \multirow{2}{*}{ Soil characteristics } & \multicolumn{2}{c}{ Soil levels } \\
\cline { 2 - 3 } & Season 1 & Season 2 \\
\hline $\mathrm{pH}(1: 2.5)$ water & 4.9 & 5.5 \\
Organic matter $\left(\mathrm{g} 100 \mathrm{~g}^{-1}\right)$ & 14.3 & 13.1 \\
Mineral N (mg N kg $\left.{ }^{-1}\right)$ & 29.4 & 4.7 \\
Olsen available phosphorus $\left(\mathrm{mg} \mathrm{kg}^{-1}\right)$ & 12.0 & 5.7 \\
Exchangeable potassium $\left(\mathrm{mg} \mathrm{kg}^{-1}\right)$ & 116 & 88 \\
Exchangeable sodium $\left(\mathrm{cmol}_{\mathrm{c}} \mathrm{kg}^{-1}\right)$ & 0.06 & 0.21 \\
Exchangeable calcium $\left(\mathrm{cmol}_{\mathrm{c}} \mathrm{kg}^{-1}\right)$ & 0.43 & 0.98 \\
Exchangeable magnesium $\left(\mathrm{cmol}_{\mathrm{c}} \mathrm{kg}^{-1}\right)$ & 0.15 & 0.29 \\
Sum of exchangeable bases $\left(\mathrm{cmol}_{\mathrm{c}} \mathrm{kg}^{-1}\right)$ & 0.94 & 1.58 \\
Exchangeable aluminum $\left(\mathrm{cmol}_{\mathrm{c}} \mathrm{kg}^{-1}\right)$ & 0.49 & 0.12 \\
Aluminum saturation $\left(\mathrm{mg} \mathrm{kg}^{-1}\right)$ & 34.5 & 7.05 \\
\hline
\end{tabular}

The potato seeds used in this study were of the genotype Desiree, current type, semi-late variety with a cultivation duration of 150-160 days, in the same field as described by IVRO-Wageningen (1964) (Contreras and Fuentealba, 1975). The crop was established on October 22, 1998. The experimental design consisted of randomized complete blocks with three repetitions. Each plot size was $5.8 \mathrm{~m}^{2}$. In each plot 36 tubers were arranged with a distance on-row of $30 \mathrm{~cm}$ and between-row of $80 \mathrm{~cm}$.

To determine the concentration of the crops nutrients, samples were collected by randomly extracting two plants from each plot (135 days after planting). The samples were separated into leaves, seeds, roots, and tubers; they were then stored in plastic bags for later weighing and drying. Once dry, the samples were 
chopped (leaves and seed) and milled (roots and tubers) separately. Total $\mathrm{N}$ concentrations were measured using the Kjeldahl-wet digestion method in addition to subsequent distillations (Sadzawka et al., 2006).

At crop establishment and harvest (150 days after planting), soil samples were collected from a depth of $20 \mathrm{~cm}$, considering an area of $80 \mathrm{~cm}^{2}$, to include the soil in the rows between and above the central row. These samples were used to determine the $\mathrm{N}$ mineral concentration in the soil $\left(\mathrm{NO}_{3}\right.$ and $\left.\mathrm{NH}_{4}\right)$ using the steam drag and subsequent titration method (Sadzawka et al., 2006).

The fertilization rate applied of $\mathrm{P}_{2} \mathrm{O}_{5}$ and $\mathrm{K}_{2} \mathrm{O}$ were 200 and $100 \mathrm{~kg} \mathrm{ha}^{-1}$, respectively. Doses above the crop's requirements were applied to avoid conditions that could limit plant growth, considering the initial values determined in the soil analysis prior to crop establishment. Also, through this soil analysis, a Magnesium deficiency was found, which was corrected with the amounts of Magnesium included in the potassium fertilizer.

For the nitrogen fertilization rate, 0-50-100-150-200 and $300 \mathrm{~kg} \mathrm{ha}^{-1}$ were applied with three replicates per treatment in randomized complete design blocks. The fertilizers used in the trials were nitrodoble $(27 \% \mathrm{~N})$, triple superphosphate $\left(46 \% \mathrm{P}_{2} \mathrm{O}_{5}\right)$ and sulpomag $\left(22 \% \mathrm{~K}_{2} \mathrm{O} ; 18 \% \mathrm{MgO}\right)$. It was not necessary to correct the aluminum saturation of the soil because the potato crop is highly tolerant to aluminum saturation (20-30\%) and a low pH (4.9) (Rodríguez et al., 2001).

Fertilization of the potato crop in the Valdivia agroecosystem was evaluated considering the nutrient demand of the crop, the supply of nutrients in the soil and the fertilization efficiency (Rodríguez et al., 2001) using the following equation (Equation 1):

Dose $=\frac{\text { Crop Nutrient Demand }- \text { Soil Nutrient Supply }}{\text { Fertilizer Efficiency }}$
This equation allowed for the analysis of the efficiency of $\mathrm{N}$ use in function of the $\mathrm{N}$ applied as fertilizer, through the optimal dose that reached maximum crop yield under dryland conditions. For this, we evaluated the parameters of the Harvest Index (HI), which indicates the proportion of all harvested dry matter produced ( $\mathrm{kg}$ tubers $\mathrm{kg}^{-1}$ MS tubers plus foliage), the tubers harvest moisture (HM) expressed in \%, and the Internal $\mathrm{N}$ Requirement (INR), which corresponds to the optimum minimum concentration of nutrients per unit of dry matter produced and is measured at the time of the crop harvest $\left(\mathrm{kg} \mathrm{N} \mathrm{kg}^{-1} \mathrm{MS}\right.$ tubers more aerial part, expressed as a percentage). "The $\mathrm{N}$ extraction index (NEI) of the tubers was also determined; this represents the extraction of $\mathrm{N}$ from the field when there is complete residue recycling. In this study, the measure was performed at 135 days after planting.

The parameters HI, $\% \mathrm{~N}, \% \mathrm{MS}$, yield, $\mathrm{N}$ uptake, etc. were further validated for the potato crop by measuring the same crop variables throughout a second season in the same dryland conditions. Two potato varieties and three levels of $\mathrm{N}$ fertilization were utilized; $0-80-140 \mathrm{~kg} \mathrm{ha}^{-1}$ were applied to the Atica variety and $0-120-200 \mathrm{~kg} \mathrm{ha}^{-1}$ to the Desiree variety. The fertilization rate applied of $\mathrm{P}_{2} \mathrm{O}_{5}$ and $\mathrm{K}_{2} \mathrm{O}$ was 400 and $300 \mathrm{~kg}$ $\mathrm{ha}^{-1}$, respectively. Diseases, insects and weeds were prevented or controlled by spraying recommended biocides as required.

The $\mathrm{N}$ use efficiency of the crop ( $\mathrm{kg}$ of $\mathrm{N}$ absorbed by plants in relation to $\mathrm{kg}$ of $\mathrm{N}$ mineral available in the soil) was determined by fitting the data to five statistical models to determine which one best described the relationship between $\mathrm{N}$ applied and tuber yield. The best fitting data that describes the $\mathrm{N}$ efficiency of the potato crop is reflected by equation 2 . 
Quadratic-Potential Model

$$
Y=a+b X^{1.08}-c\left(X^{1.08}\right)^{2}
$$

Equation 2

Quadratic Model

$$
Y=a+b X+c X^{2}
$$

Equation 3

Exponential Model

$$
Y=a+b \exp (c X)
$$

Square Roots Model

$$
Y=a+b X^{1 / 2}+c X
$$

Equation 5

Linear-Plateau Model

$$
\begin{gathered}
Y 1=a 1+b 1 X \\
Y a t X 0=b 1 X 0+a 1 \\
Y 2=Y a t X 0+b 2(X-X 0) \\
Y=I F(X<X O, Y 1, Y 2)
\end{gathered}
$$

\section{Equation 4}

Equation 6

Where $Y$ is the tuber yield $\left(\mathrm{Mg} \mathrm{ha}^{-1}\right), X$ the fertilization rate applied ( $\mathrm{kg} \mathrm{N} \mathrm{ha}^{-1}$ ), $a$ (intercept), $b$ (linear coefficient), and $c$ (coefficient of the equation) are parameters estimated in the regression analysis.

By creating a balance between the $\mathrm{N}$ contents of the soil and the $\mathrm{N}$ absorbed by the crop an estimate of the mineralized $\mathrm{N}$ can be obtained:

$$
N m=N a b s+N m f-N m i \quad \text { Equation } 7
$$

Where $\mathrm{Nm}$ is the mineralized $\mathrm{N}\left(\mathrm{kg} \mathrm{ha}^{-1}\right)$, Nabs is the $\mathrm{N}$ absorbed by the crop $\left(\mathrm{kg} \mathrm{ha}^{-1}\right), \mathrm{Nmf}$ is the mineral $\mathrm{N}$ present at harvest $\left(\mathrm{kg} \mathrm{ha}^{-1}\right)$ and $\mathrm{Nmi}$ is the $\mathrm{N}$ mineral present at planting $\left(\mathrm{kg} \mathrm{ha}^{-1}\right)$.

\subsection{Statistical analysis}

The standard deviation of the returns obtained was adjusted using the average coefficient of variation to reduce variability, excluding yields higher than the average achieved during harvest. On the other hand, the optimum rates were calculated by deriving the equation determined in each statistical model. In the square roots model, the maximum yield (ymax) was adjusted to $95 \%$ by establishing a constant value for $a$ and $b$. Regression analyses were performed using the statistical program GraphPad Prism 5.0. Analyses of variance were performed with Statistica 2.0 and Statgraphics software 7 .

\section{Results}

From the initial native $\mathrm{N}$ (29 ppm N mineral), the variation in the supply of $\mathrm{N}$ showed the conditions of crop growth under three different $\mathrm{N}$ availabilities in the soil: $\mathrm{N}$ deficiency (rates from 0 to $150 \mathrm{~kg}$ $\mathrm{N} \mathrm{ha}^{-1}$ ), optimum $\mathrm{N}$, achieved with the addition of $200 \mathrm{~kg} \mathrm{~N} \mathrm{ha}^{-1}$ (Table 2), and a supra-optimal condition in which $300 \mathrm{~kg} \mathrm{~N} \mathrm{ha}^{-1}$ were added, where the yield of commercial tubers decreased by $21.6 \%$ regarding the maximum yield obtained with a $\mathrm{N}$ dose of $200 \mathrm{~kg} \mathrm{ha}^{-1}$. Therefore, under supra-optimal conditions a negative response to nitrogen fertilization was observed (Figure 1a).

The growth conditions (deficiency, optimum and supra-optimal) found in the potato crops allowed us to assess the variation of the parameters used for the reasoned fertilization method, such as tuber HM and crop HI (Table 2). The variation of the of dry matter (DM) content when applying increasing levels of $\mathrm{N}$ was present in the foliage, seeds and roots (Table 4), which was, on average 12.7, 9.3 and $17.6 \% \mathrm{DM}$, respectively. 


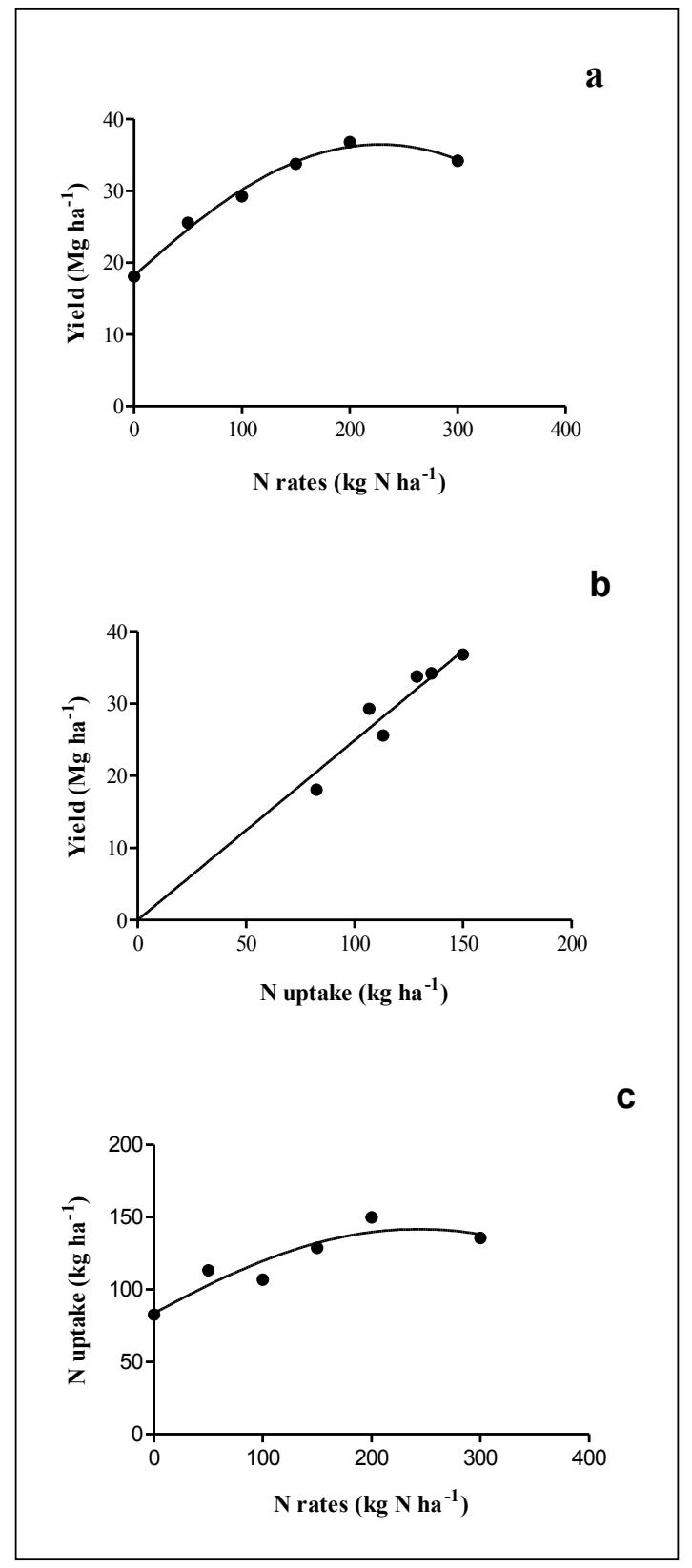

Figure 1. Relations between nitrogen absorption and production of potato tubers, applied nitrogen rate and nitrogen absorption, and rate applied and the production of tubers. 
Table 2. Yields, tubers Harvest Moisture (HM) and Harvest Index (HI), according to treatments.

\begin{tabular}{|c|c|c|c|c|c|}
\hline \multicolumn{4}{|c|}{$\mathrm{Mg} \mathrm{ha}^{-1}$ yield } & \multicolumn{2}{|c|}{ Crop parameters } \\
\hline Treatments & Commercial tubers & Cull tubers & Total & HM (\%) & $\mathrm{HI}$ \\
\hline 0 & $13.41 \pm 14.2 \mathrm{c}$ & $4.66 \pm 8.3 \mathrm{~b}$ & $18.07 \pm 6.8 \quad b$ & $80.2 \pm 0.8 \mathrm{a}$ & $0.69 \pm 0.03 \mathrm{a}$ \\
\hline 50 & $16.64 \pm 20.4 \mathrm{bc}$ & $8.93 \pm 13.6 \mathrm{a}$ & $25.57 \pm 29.1 \mathrm{ab}$ & $80.0 \pm 2.1 \mathrm{a}$ & $0.67 \pm 0.09 \mathrm{a}$ \\
\hline 100 & $20.12 \pm 33.3 \mathrm{abc}$ & $9.14 \pm 9.2 \mathrm{a}$ & $29.27 \pm 24.2 \mathrm{a}$ & $80.6 \pm 0.9 \mathrm{a}$ & $0.77 \pm 0.06 \mathrm{a}$ \\
\hline 150 & $24.63 \pm 52.2 \mathrm{ab}$ & $9.17 \pm 11.8 \mathrm{a}$ & $33.79 \pm 62.2 \mathrm{a}$ & $80.6 \pm 1.2 \mathrm{a}$ & $0.73 \pm 0.13 \mathrm{a}$ \\
\hline 200 & $30.85 \pm 8.0 \mathrm{a}$ & $5.97 \pm 7.9 \mathrm{ab}$ & $36.82 \pm 2.1 \quad \mathrm{a}$ & $79.8 \pm 1.9 \mathrm{a}$ & $0.74 \pm 0.05 \mathrm{a}$ \\
\hline 300 & $24.16 \pm 31.4 \mathrm{ab}$ & $10.06 \pm 29.0 \mathrm{a}$ & $34.21 \pm 52.6 \mathrm{a}$ & $79.9 \pm 1.5 \mathrm{a}$ & $0.79 \pm 0.06 \mathrm{a}$ \\
\hline
\end{tabular}

Different letters in the columns indicate significant differences $(\mathrm{P}<0.05$; Tukey)

These parameters showed no significant variation with the level of $\mathrm{N}$ fertility. Thus, the HM was on average $80.2 \%$, varying by $1 \%$ between rates of $\mathrm{N}$ fertilization. The HI was 0.73 on average, varying by $15 \%$ among treatments, this is attributable to high standard error values, possibly due to a greater variation in the size of the tubers in accordance with the level of $150 \mathrm{~kg} \mathrm{~N} \mathrm{ha}^{-1}$.

These non-significant variations in the evaluated parameters supported the need to evaluate these results during a second season under dryland conditions. After this second assessment, the same parameters proved to remain relatively constant when evaluated under different $\mathrm{N}$ levels, validating the previously determined reasoned $\mathrm{N}$ fertilization in potato crops (Table 3 ).
The same situation was determined for the concentration of $\mathrm{N}$ in the tubers (Figure 1b), with an average value of $1.3 \%$ and $1.4 \%$. Also, a non-significant variation was found among $\mathrm{N}$ fertilization treatments in INR (Table 6).

The concentration of $\mathrm{N}$ in foliage and roots showed a change of $67 \%$ and $47 \%$, respectively, depending on the $\mathrm{N}$ rate applied. Moreover, the extracted nitrogen $\left(\mathrm{kg} \mathrm{N}\right.$ absorbed $\left.\mathrm{ha}^{-1}\right)$ for tubers and foliage increased with an increasing $\mathrm{N}$ supply until an optimal rate of $200 \mathrm{~kg} \mathrm{~N} \mathrm{ha}^{-1}$, after which the $\mathrm{N}$ uptake declined by $9 \%$ in tubers and $10 \%$ in foliage $(P<0.05)$ with a maximum level of $300 \mathrm{~kg} \mathrm{~N}$ ha $^{-1}$ (Table 5). 
Table 3. Yield, Harvest Index (HI), $\mathrm{N}$ concentration in tubers, $\mathrm{N}$ uptake and $\mathrm{N}$ extraction according to treatments, evaluated in a second season of potato cultivation.

\begin{tabular}{|c|c|c|c|c|c|c|c|}
\hline \multicolumn{8}{|c|}{ Crop parameters of season 2} \\
\hline & Treatment & $\begin{array}{c}\text { Yield } \\
\left(\mathrm{Mg} \mathrm{ha}^{-1}\right)\end{array}$ & HI & $\% \mathrm{~N}$ in tubers & $\begin{array}{c}\mathrm{N} \text { uptake tubers } \\
\left(\mathrm{kg} \mathrm{ha}^{-1}\right)\end{array}$ & $\begin{array}{c}\text { N uptake total } \\
\left(\mathrm{kg} \mathrm{ha}^{-1}\right)\end{array}$ & $\begin{array}{c}\text { N extraction } \\
\left(\mathrm{kg} \mathrm{ha}^{-1}\right)\end{array}$ \\
\hline \multirow[t]{3}{*}{ Atica } & 0 & $18.6 \pm 1.7 \mathrm{a}$ & $0.88 \pm 0.02 \mathrm{a}$ & $1.0 \pm 0.1 \mathrm{a}$ & $37.1 \pm 0.7 \mathrm{a}$ & $44.2 \pm 0.4 \mathrm{a}$ & $44.1 \pm 0.2 \mathrm{a}$ \\
\hline & 80 & $21.4 \pm 2.4 \mathrm{a}$ & $0.88 \pm 0.02 \mathrm{a}$ & $0.9 \pm 0.2 \mathrm{a}$ & $38.1 \pm 13.2 \mathrm{a}$ & $47.3 \pm 12.5 \mathrm{a}$ & $52.1 \pm 7.2 \mathrm{a}$ \\
\hline & 140 & $18.9 \pm 2.2 \mathrm{a}$ & $0.85 \pm 0.01 \mathrm{a}$ & $0.9 \pm 0.3 \mathrm{a}$ & $33.0 \pm 15.8 \mathrm{a}$ & $46.2 \pm 20.4 \mathrm{a}$ & $52.5 \pm 12.0 \mathrm{a}$ \\
\hline \multirow[t]{3}{*}{ Desiree } & 0 & $24.9 \pm 1.5 \mathrm{a}$ & $0.85 \pm 0.01 \mathrm{a}$ & $0.8 \pm 0.1 \mathrm{a}$ & $40.2 \pm 4.1 \mathrm{a}$ & $56.3 \pm 2.7 \mathrm{a}$ & $56.2 \pm 2.6 \mathrm{a}$ \\
\hline & 120 & $32.4 \pm 3.3 \mathrm{a}$ & $0.87 \pm 0.01 \mathrm{a}$ & $0.8 \pm 0.0 \mathrm{a}$ & $51.5 \pm 4.8 \mathrm{a}$ & $69.5 \pm 4.7 \mathrm{a}$ & $69.4 \pm 4.7 \mathrm{a}$ \\
\hline & 200 & $29.4 \pm 6.1 \mathrm{a}$ & $0.85 \pm 0.02 \mathrm{a}$ & $1.0 \pm 0.0 \mathrm{a}$ & $56.910 .0 \mathrm{a}$ & $74.4 \pm 12.2 \mathrm{a}$ & $74.3 \pm 12.0 \mathrm{a}$ \\
\hline
\end{tabular}

Different letters in the columns indicate significant differences $(P<0.05$; Tukey)

Table 4. Dry matter content and N concentration in foliage, seeds and roots by treatments.

\begin{tabular}{ccccccc}
\hline & \multicolumn{2}{c}{ Foliage } & \multicolumn{2}{c}{ Seeds } & \multicolumn{2}{c}{ Roots } \\
\hline Treatment & $\% \mathrm{DM}$ & $\% \mathrm{~N}$ & $\% \mathrm{DM}$ & $\% \mathrm{~N}$ & $\% \mathrm{DM}$ & $\% \mathrm{~N}$ \\
\hline 0 & $12.8 \pm 0.9 \mathrm{a}$ & $1.9 \mathrm{ab}$ & $9.9 \pm 2.0 \mathrm{a}$ & $2.5 \mathrm{a}$ & $17.7 \pm 2.6 \mathrm{a}$ & $1.0 \mathrm{c}$ \\
50 & $13.0 \pm 0.8 \mathrm{a}$ & $1.0 \mathrm{~b}$ & $8.5 \pm 0.6 \mathrm{a}$ & $2.1 \mathrm{a}$ & $16.6 \pm 2.7 \mathrm{a}$ & $1.0 \mathrm{bc}$ \\
100 & $13.0 \pm 0.9 \mathrm{a}$ & $0.9 \mathrm{~b}$ & $9.5 \pm 1.8 \mathrm{a}$ & $2.4 \mathrm{a}$ & $17.4 \pm 2.2 \mathrm{a}$ & $1.2 \mathrm{abc}$ \\
150 & $12.6 \pm 0.8 \mathrm{a}$ & $1.0 \mathrm{~b}$ & $9.5 \pm 1.1 \mathrm{a}$ & $2.4 \mathrm{a}$ & $18.4 \pm 2.8 \mathrm{a}$ & $1.4 \mathrm{abc}$ \\
200 & $12.3 \pm 0.8 \mathrm{a}$ & $1.8 \mathrm{ab}$ & $9.1 \pm 2.0 \mathrm{a}$ & $2.4 \mathrm{a}$ & $18.9 \pm 2.8 \mathrm{a}$ & $1.7 \mathrm{a}$ \\
300 & $12.4 \pm 1.1 \mathrm{a}$ & $2.7 \mathrm{a}$ & $9.2 \pm 1.6 \mathrm{a}$ & $2.6 \mathrm{a}$ & $17.0 \pm 2.0 \mathrm{a}$ & $1.5 \mathrm{ab}$ \\
\hline
\end{tabular}

Different letters in the columns indicate significant differences $(P<0.05$; Tukey) 
Table 5. Nitrogen extracted by tubers, foliage and seeds in each treatment.

\begin{tabular}{ccccc}
\hline \multicolumn{5}{c}{ Kg N uptake ha ${ }^{-1}$} \\
\hline Treatment & Tubers & Foliage & Seeds & Total \\
\hline 0 & 49.5 & 24.4 & 8.5 & $82.5 \pm 10.5 \mathrm{~b}$ \\
50 & 72.4 & 29.0 & 11.8 & $113.2 \pm 25.9 \mathrm{ab}$ \\
100 & 77.8 & 21.7 & 7.3 & $106.7 \pm 8.6 \mathrm{ab}$ \\
200 & 86.4 & 32.9 & 9.3 & $128.7 \pm 15.6 \mathrm{a}$ \\
300 & 98.8 & 43.3 & 7.8 & $149.9 \pm 14.6 \mathrm{a}$ \\
\hline
\end{tabular}

Different letters in the columns indicate significant differences $(P<0.05$; Tukey)

Table 6. Internal Nitrogen Requirement (INR), Values of Nitrogen Extraction Index (NEI) and Residual mineral nitrogen in the soil post-harvest, considering the estimated recovery efficiency of nitrogen fertilizer for the potato crops of each treatment.

\begin{tabular}{ccccc}
\hline Treatment & $\begin{array}{c}\text { INR } \\
(\mathrm{g} \mathrm{100} \mathrm{g})\end{array}$ & $\begin{array}{c}\mathrm{NEI} \\
\left({\left.\mathrm{g} 100 \mathrm{~g}^{-1}\right)}^{-1}\right)\end{array}$ & $\begin{array}{c}\text { Residual N } \\
\left(\mathrm{mg} \mathrm{kg}^{-1}\right)\end{array}$ & $\begin{array}{c}\text { Efficiency } \\
\left(\mathrm{g} \mathrm{100}^{-1}\right)\end{array}$ \\
\hline 0 & $1.6 \pm 0.10 \mathrm{a}$ & $60.2 \pm 0.96 \mathrm{a}$ & $39.2 \pm 5.01 \mathrm{~d}$ & 0 \\
50 & $1.5 \pm 0.03 \mathrm{a}$ & $65.2 \pm 8.44 \mathrm{a}$ & $43.9 \pm 7.70 \mathrm{~d}$ & 59.9 \\
100 & $1.5 \pm 0.10 \mathrm{a}$ & $72.9 \pm 6.37 \mathrm{a}$ & $84.0 \pm 19.44 \mathrm{~cd}$ & 34.3 \\
150 & $1.4 \pm 0.14 \mathrm{a}$ & $64.9 \pm 13.94 \mathrm{a}$ & $109.0 \pm 43.12 \mathrm{bc}$ & 30.9 \\
200 & $1.5 \pm 0.09 \mathrm{a}$ & $65.7 \pm 5.14 \mathrm{a}$ & $148.6 \pm 14.04 \mathrm{ab}$ & 29.3 \\
300 & $1.6 \pm 0.19 \mathrm{a}$ & $66.1 \pm 6.55 \mathrm{a}$ & $186.2 \pm 14.58 \mathrm{a}$ & 15.4 \\
\hline
\end{tabular}

Different letters in the columns indicate significant differences $(P<0.05$; Tukey) 
The Nitrogen Extraction Index (NEI) showed no significant differences, where the average value was $66.5 \%$ of the total $\mathrm{N}$ uptake, presenting a variation between 60 and $73 \%$ among treatments. A close relationship between the $\mathrm{N}$ applied and the residual $\mathrm{N}$ from fertilizer applications was observed in the postharvest soil samplings. Higher rates of $\mathrm{N}$ fertilization increased the amount of mineral $\mathrm{N}$ remaining by $21.5 \%$ from the initial mineral $\mathrm{N}$ found in the soil (control) to the maximum rate applied, $300 \mathrm{~kg} \mathrm{~N} \mathrm{ha}^{-1}$ (Table 6). This relationship was described by a linear equation $\left(\mathrm{R}^{2}=0.97\right.$; data not shown):

$$
Y=30.78+0.5327 X \quad \text { Equation } 8
$$

According to balance between the $\mathrm{N}$ contents of the soil and the $\mathrm{N}$ absorbed by the crop (Figure 1), it can be assumed that for this test the soil mineralized, on average, an equivalent of $140 \mathrm{~kg} \mathrm{~N} \mathrm{ha}^{-1}$ of which the unfertilized crop would have been able to recover $67 \%$.

\subsection{Nitrogen recovery efficiency}

The yield response to an increasing supply of $\mathrm{N}$ varied among the five models used. Table 7 presents an appropriate adjustment to describe this variation, explaining a large proportion of this variability through the coefficient of determination with $\mathrm{R}^{2}$ values $>0.90$. However, the optimal rate determined by each fertilization model showed a $14 \%$ variation among models. For this study, the quadratic-potential model adequately represents the concept of crop response to $\mathrm{N}$ fertilization with a degree of correlation $\mathrm{R}^{2}=0.96$, described by the following equation:

$Y=183+1.033 X^{1.08}-0.001466\left(X^{1.08}\right)^{2}$

Equation 9

The relationship between the $\mathrm{N}$ doses and the potato yield reached a physical optimal of productivity at a rate of $228 \mathrm{~kg} \mathrm{~N} \mathrm{ha}^{-1}$ (Figure 1a).

Table 7. Optimal rate of nitrogen $\left(\mathrm{kg} \mathrm{N} \mathrm{ha}^{-1}\right)$ calculated for five statistical models for total yield $\left(\mathrm{Mg} \mathrm{ha}^{-1}\right)$ of the crop.

\begin{tabular}{ccccc}
\hline Model & Optimal Dose & Yield & Sy.x & $\mathrm{R}^{2}$ \\
\hline Quadratic-Potential & 228 & 36.49 & 1.39 & 0.9611 \\
Quadratic & 230 & 36.16 & 1.41 & 0.9597 \\
Linear-Plateau & 180 & & & \\
Exponential & 130 & 37.33 & 1.52 & 0.9566 \\
Square roots & 322 & 32.25 & 1.87 & 0.9294 \\
\hline
\end{tabular}

Sy.x: standard deviation equation; $\mathrm{r}^{2}$ : coefficient of determination. 


\section{Discussion}

The internal $\mathrm{N}$ concentration of crop organs remained relatively constant (no significant differences, $P>$ 0.05 ) regardless of whether there was deficient, optimal or supra-optimal $\mathrm{N}$ available; hence, the variation in crop uptake proved to depend on the utilization efficiency of the crop to develop biomass with an increasing supply of $\mathrm{N}$. Therefore, the increase in total tuber yield due to higher $\mathrm{N}$ applications in deficient and optimal $\mathrm{N}$ situations was due to greater crop biomass development, generating more synthesis and translocation of photosynthates from the foliage to the tubers (Kumar et al., 2007). On the contrary, supra-optimal $\mathrm{N}$ availability conditions have proven to cause a decrease in potato crop yields (Pérez et al., 2008; Morales et al., 2013) and may also have detrimental effects on tuber quality and the environment (Goffart et al., 2011; Khan et al., 2014). This suggests that the plant cannot dilute such excessive $\mathrm{N}$ concentrations appropriately in terms of shape and proportion throughout its dry matter. In this case, we observed a decrease in the absorption of $\mathrm{N}$ with a maximum rate of $300 \mathrm{~kg} \mathrm{~N} \mathrm{ha}^{-1}$ (although the difference was not statistically significant, $P>0.05$ ), coinciding with a decline in tuber yield caused by an initial phytotoxicity. This rate of $\mathrm{N}$ application handicapped the emergence and further development of plant (Fontes et al., 2010). A crop is total dry matter production and $\mathrm{kg}$ of $\mathrm{N} \mathrm{ab}$ sorbed can be used to calculate the internal nitrogen requirement for that crop (Ojala et al., 1990; Sun et al., 2012). The slight variation (no significant differences, $P>0.05$ ) of the internal $\mathrm{N}$ concentrations found in this work allows us to use the parameters of internal requirement in different situations of $\mathrm{N}$ availability and generate recommendations to calculate an effective amount of nitrogen fertilization for the potato crop (Gayler et al., 2002; Perez et al., 2008). Also, the significant non-variation of the NEI may be be- cause tubers' objective is to accumulate carbohydrates and, to a lesser extent, proteins that are nitrogen-rich (Snapp et al., 2004).

Generally, the potato crop presents a relatively low ability to take up available soil mineral nitrogen (Goffart et al., 2008). Also, the fact that the NEI of tubers represents the extraction of $\mathrm{N}$ from the field when there is a complete recycling of waste suggests that previous soil management has a clear effect on the contribution of $\mathrm{N}$ to current potato crops (INIA, 2002). Clearly the increased residual $N$, along with the increasing rate of $\mathrm{N}$ applied to each crop, allow us to visualize the possibility of a supra-optimal nitrogen fertilization condition or an accumulation of residual mineral nitrogen that may be contaminating the environment (Sharifi et al., 2007). Also, N mineralized from sources organic of soil could be more relevant than the type of fertilizer applied in the Nitrogen availiabiity in an Andisol during season growing of the crop, being a determining factor to consider in fertilizer strategies in southern Chilean Agroecosystems to avoid $\mathrm{N}$ losses (Martínez-Lagos et al., 2015).

When an agro-ecosystem undergoes a water deficit, crop yield increases when it has higher total available soil nitrogen, but the yield response diminishes as the amount of total seasonal water decreases (Ojala et al. 1990). Therefore, although nitrogen fertilization does not affect the moisture content of the crop tubers or foliage (Pérez et al, 2008), adequate water availability is essential for the proper development of potatoes in an agro-ecosystem. Small variations of the evaluated productive parameters (HM and $\mathrm{HI}$ ) did arise in the dryland conditions of the agro-ecosystem where this study was carried out. Other studies have shown that such parameters vary, increasing or decreasing their values in relation to the absorption capacity of $\mathrm{N}$ an increasing rates supplies with changing of agroecosystem used (Vos, 1997; Jamaati-e-Somarin et al., 2010; Kołodziejczyk, 2014). 


\subsection{Reasoned fertilization and crop $N$ response}

The optimal rate variation among models is mainly due to statistical function that describes the yield response; this most likely overestimates or underestimates the physical optimum rate of $\mathrm{N}$ fertilization. In this sense, Cerratto and Blackmer (1990) concluded, after comparing models to describe the yield response to $\mathrm{N}$ fertilization in corn that the linear-plateau model tends to overestimate the yield in the response curve close to the optimum level of $\mathrm{N}$. This is consistent with the nature of this model, which has an abrupt discontinuity, which is difficult to biologically justify, resulting in the identification of an optimal $\mathrm{N}$ level that was too low. Moreover, the exponential model tended to underestimate yield at the rates of fertilization it identified as optimum, whereas the square root model either underestimated or overestimated yield at rates of $\mathrm{N}$ fertilization greater than the optimum $\mathrm{N}$ rate (Belanger et al., 2000). Thus, it has been shown that the model of square roots underestimates the yield response, projecting optimum rates higher $(709 \mathrm{~kg}$ $\mathrm{ha}^{-1}$ ) than the quadratic model, which tends to overestimate the level of $\mathrm{N}$ and predicts a rapid decline in yield when the fertilizer applied is greater than the optimum rate. It has therefore been concluded that the quadratic-plateau model best represents the relationship between the $\mathrm{N}$ level and yield in the cultivation of corn, producing more rational results from an agricultural point of view (Cerratto and Blackmer, 1990; Pagani et al., 2008).

For potato crops, Belanger et al. (2000) evaluated and compared three statistical models (quadratic, exponential and square root) and concluded that the quadratic model is best suited to describe the yield response of potatoes to $\mathrm{N}$ fertilizer, presenting less biased data. Thus, Fontes et al. (2010) used a quadratic model to represent the relationship between the applied dose of $\mathrm{N}$ and the $\mathrm{N}$ absorbed by potato crops. For this reason, the data in this study was adjusted with a quadratic-potential best model describing the best relationship between the $\mathrm{N}$ supply and the potato crop yield in an Andisol.

\subsection{Nitrogen recovery efficiency}

Kołodziejczyk (2014) determined that each increase in the rate of nitrogen fertilization caused a decrease in the $\mathrm{N}$ use efficiency, corroborating the data determined in this study. Although the rate of $300 \mathrm{~kg} \mathrm{~N} \mathrm{ha}^{-1}$ turned out to be excessive, apparently toxicity caused by the excess of the initial $\mathrm{N}$ inhibited its subsequent absorption, causing the crop to eventually absorb less $\mathrm{N}$ and produce fewer tubers. It is likely that this effect altered the relationship of the standard curve observed in other crops once they reached their maximum yield; absorption can increase without increasing production (luxury consumption).

\section{Conclusions}

Three $\mathrm{N}$ availability situations were established (deficient, optimal and supra-optimal), where the behavior of the evaluated parameters allowed us to estimate when the $\mathrm{N}$ use efficiency of potato crops decreased due to excess fertilization, causing excessive increases in the residual $\mathrm{N}$ in an Andisol. Thus, the information obtained with this methodology is useful for planning the nitrogen fertilization of a soil since it aids in estimating the $\mathrm{N}$ extractions, losses and incomes to a system in relation to the crop and its expected yield, allowing us to determine an optimal fertilization rate for potato crops in a given agro-ecosystem. 


\section{References}

Belanger, G., Walsh, J., Richards, J., Milburn, P., Ziadi, N. 2000. Comparison of Three Statistical Models Describing Potato Yield Response to Nitrogen Fertilizer. Agron J. 92: 902-908.

Cerratto, M., Blackmer, A. 1990. Comparison of Models for Describing; Corn Yield Response to Nitrogen Fertilizer. Agron J. 82:138-143.

Contreras, A., Fuentealba, J. 1975. Eficiencia y tuberización de cultivares de papa (Solanum tuberosum L.). Agro Sur. 3: 92-97.

Fontes, P., Braun, H., Busato, C., Cecon, P. 2010. Economic Optimum Nitrogen Fertilization Rates and Nitrogen Fertilization Rate Effects on Tuber Characteristics of Potato Cultivars. Potato Res. 53:167-179.

Garnet, T., Conn, V., Kaiser, B. 2009. Root based approaches to improving nitrogen use efficiency in plants. Plant Cell. Environ. 32: 1272-1283.

Gayler, S., Wang, E., Riesack, E., Schaaf, T., Maidl, F. 2002. Modeling biomass growth, N-uptake and phenological development of potato crop. Geoderma. 105: 367-383.

Giletto, C.M., Echeverria, H.E., Sadras, V. 2003. Fertilización nitrogenada de cultivares de papa (Solanum tuberosum) en el sudeste Bonaerense. Ciencia del Suelo. 21: 44-51.

Goffart, J.P., Olivier, M., Frankinet, M. 2008. Potato Crop Nitrogen Status Assessment to Improve N Fertilization Management and Efficiency: PastPresent-Future. Potato Res. 51: 355-383.

Goffart, J., Oliver, M., Frankinet, M. 2011. Crop Nitrogen Status Assessment Tools in a Decision Support System for Nitrogen Fertilization Management of Potato Crops. Hort Technology. 21: 282-286.
Instituto Nacional De Investigación De Recursos Naturales (IREN) - CORFO - Universidad Austral De Chile. 1978. Estudio de suelos de la provincia de Valdivia., Santiago, 178 p.

Instituto De Investigación Agropecuarias (INIA). 2002. Manual fertilización del cultivo de la papa en la zona sur de Chile, Santiago, 104 p.

Jamaati-e-Somarin, S., Zabihi-e-Mahmoodabad, R., Yari, A. 2010. Yield and yield components of potato (Solanum tuberosum L.) tuber as affected by nitrogen fertilizer and plant density. Aust J. Basic Appl. Sci. 4: 3128-3131.

Khan, I., Zaman, M., Khan, M. J., Iqbal, M., Babar, M. N. 2014. How to improve yield and quality of potatoes: effects of two rates of urea N, urease inhibitor and Cytozyme nutritional program. J. Soil Sc. Plant Nutr. 14: 268-276.

Kołodziejczyk, M. 2014. Effectiveness of nitrogen fertilization and application of microbial preparations in potato cultivation. Turk. J. Agric. For. 38:299-310.

Kumar, P., Pandey, S., Singh, B., Singh, S., Kumar, D. 2007. Effect of nitrogen rate on growth, yield, economics and crisps quality of indian potato processing cultivars. Potato Res. 50: 143-155.

Kraiser, T., Gras, D. E., Gutierrez, A. G., Gonzalez, B., Gutierrez, R. A. 2011. A holistic view of nitrogen acquisition in plants. J. Exp. Bot. 62: 145566.

Luzio, W., Casanova, M. 2006. Avances en el conocimiento de los suelos de Chile. Uuniversidad de Chile y Servicio agrícola y ganadero (SAG). Santiago, $393 \mathrm{p}$.

Martínez-Lagos, J., Salazar, F., Alfaro, M., Rosas, M., Macías, F. 2015. Nitrogen mineralization in a silandic andosol fertilized with dairy slurry and urea. J. Soil Sc. Plant Nutr. 15: 60-75. 
McAllister, C.H., Beatty, P.H., Good, A.G. 2012. Engineering nitrogen use efficient crop plants: the current status. Plant Biotechnol. J. 10: 1-25.

Montemurro, F., Maiorana, M., Ferri, D., Convertini, G. 2006. Nitrogen indicators, uptake and utilization efficiency in a maize and barley rotation cropped at different levels and sources of $\mathrm{N}$ fertilization. Field Crop Res. 99: 114-124.

Morales, J.L., Hernández, J., Rebollar, S. 2013. Rendimiento de papa con fuentes de fertilización mineral en un Andosol del Estado de México. Revista Mexicana de Ciencias Agrícolas. 4: 881-893.

Moral, F.J.; Rebollo, F.J. 2017. Characterization of soil fertility using the Rasch model. J. Soil Sci. Plant Nutr. 17: 486-498.

Ojala, J., Stark, J., Kleinkopf, G. 1990. Influence of irrigation and nitrogen management on potato yield and quality. Am. Potato J. 67: 29-43.

Pagani, A., Echeverria, H., Sainz Rosas, H., Barbieri, P. 2008. Dosis óptima económica de nitrógeno en maíz bajo siembra directa en el sudeste bonaerense. Revista ciencia del suelo. 26:183-193.

Pérez, L.C., Rodríguez, L.E., Gómez, M.I. 2008 Efecto del fraccionamiento de la fertilización con N, P, K y Mg y la aplicación de los micronutrientes B, Mn y $\mathrm{Zn}$ en el rendimiento y calidad de papa criolla (Solanum phureja) variedad Criolla Colombia. Agronomía Colombiana. 26:477-486.

Pinochet, D. 2005. El sistema de Recomendación de fertilización de cultivos extensivos en Chile. In: F. García, G. Micucci (Eds). Simposio Fertilidad 2005. Nutrición, Producción y Ambiente. INPOFOS /Fertilizar. Rosario, Argentina, pp: 35-39.

Rens, L., Zotarelli, L., Cantliffe, D., Stoffella, P., Gergela, D., Fourman, D. 2015. Biomass accumulation, marketable yield, and quality of atlantic potato in response to nitrogen. Agron J. 107: 931-942.
Rodríguez, J., Pinochet, D., Matus, F. 2001. Fertilización de los cultivos. Editorial LOM. Santiago, Chile, $117 \mathrm{p}$.

Sadzawka, A., Carrasco, M.A., Grez, R., Mora, M.L., Flores, H., Neaman, A. 2006. Métodos de análisis recomendados para los suelos de Chile. Centro regional de investigación La Platina. Santiago, 164 p.

Sharifi, M., Zebarth, B., Burton, D., Grant, C., Porter, G., Cooper, J., Leclerc, Y., Moreau, G., Arsenault, W. 2007. Evaluation of laboratory-based measures of soil mineral nitrogen and potentially mineralizable nitrogen as predictors of field-based indices of soil nitrogen supply in potato production. Plant Soil. 301: 203-214.

Snapp, S., Long, C., Douches, S., Chase, R. 2004. Tuber yield, storability, and quality of michigan cultivars in response to nitrogen management and seed piece spacing. Am. J. Potato Res. 81: 347357.

Sun, L., Gu, L., Peng, X., Liu, Y., Li, X., Yan, X. 2012. Effects of nitrogen fertilizer application time on dry matter accumulation and yield of chinese potato variety KX 13. Potato Res. 55: 303-313.

Tisdale, S., Nelson, W., Beaton, J., Havlin, J. 1993. Soil fertility and fertilaizers. Fifth Edition. MacMillan Publishing Company. New-York, USA, $634 \mathrm{p}$.

Tyler, K., Broadbent, F., Bishop, J. 1983. Efficiency of nitrogen uptake by potatoes. Am. Potato J. 60: 261-269.

Vos, J. 1997. The nitrogen response of potato (Solanum tuberosum L.) in the field: nitrogen uptake and yield, harvest index and nitrogen concentration. Potato Res. 40, 237-248. 